\title{
Preparing Students for the Onslaught of Technology
}

\author{
Wilbur C. Rich \\ Wellesley College, Wellesley, MA, USA
}

\section{wrich@Wellesley.edu}

This paper will examine the various predictions about how technology will transform society. We live in an era of rapid technological development and deployment. Teachers are expected to prepare student for this onslaught on biomedical breakthroughs automation and communication/computer tools. In light of these advances, students need to be anticipatory and congruent with rapidly changing technologies. What should they know about technological uncertainty and security? Technological dependency? Information overload? Technology/human relations? How can we, as teachers, stimulate a discourse about technology and changes in the workplace? What should we know about futurists' predictions for the next decade? What should be the pedagogical strategy as the $21^{\text {st }}$ century becomes more technologically sophisticated? The paper will raise these questions as a stimulus for further discussion.

Keywords: Future, human behavior, scenario, students, technology

\section{Introduction}

"May you live in exciting time" is an old Chinese curse that captures our rapidly changing technological world. Ours is an exciting time full of exclamations such as "Wow, how did they do that? Great, what is next? Scientific progress and breakthroughs can generate excitement and apprehension. Changes in computer design, genetic research, robotics and global communication capacity have opened a new discourse about the future of human relations, production and consumption. Ray Kurzweil, the singularitarian, predicts that in the 20 to 40 years technological changes will be so rapid, human capacity will be expand exponentially (Kurzweil, 2005). Many dismiss writers like Kurzweil as a technological optimist or worse. They believe the actual human future will be less dramatic and more along the lines of a manageable pace. Regardless of which prediction proves correct, we need to know more about these projected scientific breakthroughs in order to understand how these new inventions will affect our lives. It is incumbent upon us to be alert to the promise and downside of technology. Technology cannot be safely ignored. Yet many people remain either technologically illiterate or apathetic or adverse (Dugger, 2001).

This paper acknowledges the debate about the future of technology and its relationship to human development. It also accepts rapid pace and ubiquity of technological developments and offers

Material published as part of this publication, either on-line or in print, is copyrighted by the Informing Science Institute. Permission to make digital or paper copy of part or all of these works for personal or classroom use is granted without fee provided that the copies are not made or distributed for profit or commercial advantage AND that copies 1) bear this notice in full and 2) give the full citation on the first page. It is permissible to abstract these works so long as credit is given. To copy in all other cases or to republish or to post on a server or to redistribute to lists requires specific permission and payment of a fee. Contact Publisher@InformingScience.org to request redistribution permission. suggestions for ways teachers can alert students to the opportunities and pitfalls associated with them. It is aimed not only to teachers in information technology or the history of science, but all teachers. 


\section{The Pace of Technological Change}

In the past we had a grace period before embracing a new invention. As the pace of technological change has increased exponentially, the time it takes to dream up a product, invent it and produce it has been abbreviated. Although the electrical motor was discovered in 1831, it took fifty years to put it into production. The integrated circuit was conceived of in 1958, but it took 3 years to put it into production. Today, some computer software takes considerable less time. Kurzweil envisions three related GNR revolutions-genetics, nanotechnology and robotics (i.e. strong Artificial Intelligence) will grow exponentially. In this creative environment, new ideas will be produced every day and travel as fast. Theorists, researchers and inventors have almost instant access to new ideas. They engage in fierce competition to use these new findings and insights.

The stereotype of an obscure scientist working alone in a small laboratory unconcerned about the profit potential of the research is misleading. Actually there are teams of scientists searching for solutions and breakthroughs. The competition for the services of these scientists is intense. Private companies compete openly with universities for the best researchers. In doing so, they offer a variety of perks and benefits. To lure these individuals these companies have sought the assistance of the host cities (Roche, 1997). Some host cities are redesigning their structure to attract the so-called "creative class" (Bartlett, 1991). Richard Florida asserts "All of the factors that go into creative class location decisions are, together, so powerful that I have coined a term to sum them up: quality of place" (Florida, 2005, p. 231). What is at stake are the new jobs and the city image, so catering to this class is imperative. The research and development entrepreneurs have created entire communities such as Silicon Valley, Route 128 in Boston and the Research Triangle in Raleigh/Durham dedicated to producing everything from computer software to biomedical research.

The rush to create has now taken on a global dimension. Nations, like Japan and Germany, match American production and consumption of technology. Developing countries, like India and China, are investing in the infrastructure to join the new economy. These countries are not interested in an ancillary role in production and consumption but want to be players. Given the globalization of the communications system, it will not take long before they will be able to compete with the more developed nations. As Thomas Friedman has asserted, the world has been flattened (Friedman, 2005).

\section{Making and Marketing Things}

New technologies are marketed as if work or life cannot continue without the latest new tool (McLuhan \& Fiore, 1967). People are easily convinced that the new product renders the old one obsolete, and so they are obligated to buy the new one. Reading the science magazines, one is greeted with reviews of several prototype devices in the production pipeline that will improve the workplace. In fact, millions of dollars are being invested in anthropoids (man-like machinesAdvanced Step in Innovative Mobility- ASIMO) and advanced clerical machines. There is also considerable work being done with virtual reality in order to make it more accessible and a useful tool. The talk of artificial intelligence, implanted electronic tags, robots, face recognition security devices, smart medicine, nutraceuticals (i.e., disease curing foods) and self-aware computers can be described in one word -seductive.

We are inventing machines before we have a clear idea how we plan to use them (e.g. nanotechnology). Finding things for machines to do attracts some of the best minds in the scientific world. In the workplace, machines are replacing humans in mindlessly repetitive jobs. The "paperless office” threatens to displace an army of clerical workers. Jeremy Riflin's The End of Work warns us that work as we know it may disappear (1995). It is not just the factory workers that have to worry but also many service professors may be displaced. Alan Blinder goes further claiming 
only personal service jobs are safe from off shoring (Blinder, 2006). Why are we rushing to replace and displace humans? Arthur Hunt observes

Glitzy machines have a way of mesmerizing us so that we do not think about the unintended consequences they create. Our situation today is very much like a train that we have all boarded with enormous enthusiasm. With great splendor the train embarks from the station while we cheer, "Onward! Forward!” The train picks up speed and we all shout, "Progress! Prosperity!” Faster and faster the wheels turn. With tremendous velocity the train races down the track. "Faster! Faster!” we yell. But we don't even know where the train is taking us. We don't know where it is going. It is a mystery train (Hunt, 2000, p. 2).

Teachers are also passengers on this train. Many have supported technological change while others have harbored reservations about its impact. Still others believe technology will be the bane of our existence. A few are indifferent. Regardless of our views about technology, students get messages from a teacher's reaction to changes in technology. Accordingly, it is incumbent upon teachers to fully understand these new trends.

\section{Three Views of Technology and Human Reactions}

The relationship of technology to the human condition is a controversial issue that lends itself to a variety of views. The utopian view of technology is the key to discovering the answer to most of problems of the human condition. Technology will not only improve the human condition but enhance it as well. Inventing new tools is part of being human. Human beings are evolving and the next step will require an expansion of human intelligence. To do this it will be necessary to design computers to think like humans. This will require us to reverse-engineer the human brain. At that point we would have moved into the area of non- biological intelligence. The writing of Ray Kurzweil predicts such a move in the near future. Kurzweil believes technology will solve world hunger, eliminate disease, create renewable energy, etc. For these true believers the postscarcity society is just around the corner. Science, given time, will overcome most, if not all, human illnesses and limitations. Humans will transcend our biology. Joel Garreau (2005) has called this type of thinking the heaven scenario. In this scenario, the growth of technology offers the opportunity to create more goods and make them more available to more people. Each breakthrough creates new opportunities and new careers.

Bill Gates' book The Road Ahead takes a similar optimistic view about the fruits of technology. Although technology will create electronic clearinghouses that demand more knowledge workers and more global competition, there is a silver lining. According to Gates, there will be some displacement but new work will be discovered and new careers developed. With planning and enabling political structures these optimists hope to anticipate everything from worker displacements, energy shortages, natural catastrophes etc. They dismiss all pessimistic scenarios for a technologically advanced society and declare them wrongheaded. Harris, Handel, and Mishel (2004) argued that the 1983 Nation at Risk Report's prediction of worker skills deficits was wrong.

Moreover, U.S. worker skills have grown, slowly and steadily. Employer requirements have also grown--though not nearly as fast as the pace of technological change. Indeed, it appears that technology is as likely to simplify jobs, as it is to complicate them. The evidence suggests that worker skills are not only higher than in the past, but also quite comparable with workers in other countries. The same is true of U.S. worker productivity, which also compares well with our economic competitors (Harris et al, 2004, p. 59).

Does this conclusion still hold true? In the 2006 State of the Union Address President George W. Bush mentioned China and India as competitors in the labor market. He could have mentioned other nations as well. The eclipse of American automobile industry suggests that the global com- 
petition can cause serious economic dislocation. Automation and better advertising did not prevent these companies from losing market share. President Bush believes that American workers can compete with any workers as long as there is a level ground. The level ground is defined as an international production arena in which there are no government subsidies and equal wages for the same work. The market forces have ignored international boundaries and threaten to invade most aspects of work. This example feeds into dystopian discourse.

Dystopians view technology as having a hidden dark side that will bring new and unanticipated problems. This is what Joel Garreau calls the hell scenario. In this scenario technology will eventually pose a threat to our way of life. Indeed, the current achievements in technology are requiring more resources than anticipated. The Achilles' heel of any technological juggernaut is cheap and plentiful energy. James Howard Kunstler's The Long Emergency: Surviving the Converging Catastrophes of the Twenty-First Century predicts the end of cheap oil will undermine the American way of life (2005). Most of the American economy is based on cheap and available oil. Without it the quality of life for all Americans will deteriorate. Dystopians do not believe alternative fuel can be discovered fast enough for the growing demand for energy. Technology will not be able to meet the catastrophes that will be caused by the depletion of fossil fuel. Scarcity will increase and intensify existing socio-economic inequalities. Dystopians believe that the economic gap between the haves and have-nots will become more apparent. The welfare state will grow not shrink, as more people become dependent on it. They also believe that there are untold possibilities of unforeseen social problems. James Beniger's The Control Revolution suggests information technology will enable the powerful to impose more control on all aspect of life (1986). Will privacy, as we know it, be imperiled? In 2000 a National Journal editorial questioned the ability of Congress to protect privacy.

But can Capitol Hill really legislatively stop the sometimes dirty work of a new generation of electronic peeping toms, secret stalkers, and data trackers? It can try, but Congress will probably never be able to write enough laws to keep up with the constantly evolving technology of the new "e-universe"-where information is generated, sent, and stored at speeds and in quantities that defy the imagination. Indeed, some privacy advocates in Congress wonder whether there is a cyberspace equivalent of a privacy arms race: as fast as new communications technologies appear, so do new capabilities for diverting information in unintended ways (Posner,2000, p. 1).

Increasingly, societies have been less reticent about monitoring the communications and behaviors of its members. This oversight includes colleges and universities. Students who use the university Internet connections to download certain materials or to make threats will be detected. Technology such as video cameras and electronic sensor badges allow employers to watch and monitor the movement of employees. These inventions make monitoring less costly and less visible. For the next generation, it could means being on stage all day. This can be difficult and stressful.

This is particularly true for the workplace. The Internet, once thought to ultimate communicating liberating technology, is now the most effective monitoring tool for top management. Management can and do read material sent or received at the workstations. If the company owns the machine, they have a right to restrict what is downloaded from or onto them.

There are monitoring systems that measure the amount of time spent away from computer and systems that monitor people in the building. Gaye Mack observed that the "new technology gives managers all sorts of invasive ways to watch how workers spend their time, down to the smallest second. Such monitoring creates a tremendous amount of stress on the individuals and, because of that, it can become hazardous to one's health” (cited in Laabs, 1992). It may be impossible to cre- 
ate a security-proof communication system. Organization members may become slightly paranoid if they know they are being monitored. It is not exactly George Orwell's 1984, but it is close. The ubiquitous telescreens are not upon us but it is just a matter of advancement of technology.

Dystopians views are expressed well in Aldous Huxley’s Brave New World (1932) and William Knoke's Bold New World (1996). Both paint a picture of a world transformed by technology. Huxley worries about a world being dominated by experts and a government that manipulates the labor class. In this world, the labor class will be kept docile and high on drugs. Knoke worries about a world in which everything is everywhere. It is a placeless society that is highly globalized. He also worries about the backlash by religionists against modernity, the decline of labor unions and a trend toward world government.

Francis Fukuyama's The PostHuman Future worries how the unregulated technological development could alter humans and thereby human dignity (2002). Bruce Bimber goes so far as to suggest that technology has altered the nature of democracy (2003). People can use technology as a surrogate for personal political involvement. Rather than enhancing political choices and information, it makes direct political involvement less likely. Fewer people will get involve, allowing narrow single-issue interest groups to dominate the political process.

Lastly, the dystopians like Alvin Toffler worry about the human capacity overload (1970). Can humans adapt fast enough to manage the changes technology entails? For Toffler there is a possibility of an overabundance of goods and ideas. Other intellectuals worry that a transient society will isolate people and make it difficult to make meaningful personal relationships. Such a society will allow any lifestyle to flourish but require less human interaction. Without interaction how can we build social capital necessary for human progress?

The third view may be called humanist view. This view holds that human beings have always triumphed over technology. Technology has changed human produce things and relation to each other, but in the final analysis humanity rises after every chaotic period in human history. Joel Garreau calls this a prevail scenario. Human will overcome the odds and triumph over any technological advance. Managing technology will certainly be the burden but it is a welcome challenge for this generation. Society will decide what should be done, when it should be done and where. While they are contemplating these decisions unexpected and unwelcome technological breakthroughs will interrupt the discourse. We might not extend human life indefinitely but we may be able to create a world where each life has high chance of good health. This scenario is even more optimistic than the heavenly one. It assumes that what make us human is unique and can stand the test of time. We believe in this and this mythos is reflected in our religions and secular literature.

Teachers, regardless of their specialty or views of the future, must prepare the next generation of workers for a world inundated with new technology and led by what Richard Florida calls the "creative class" (Florida, 2002). The impulse will be to provide them with a heavy dose of humanism. In spite of this, the pedagogical challenge will not be to take sides but integrate these competing and often extravagant claims into a discourse about human choices.

\section{Pedagogy Challenges and Technologic Ethos}

Students who enter a more intensive creative workplace must be trained differently. Theirs will be a world of rapid and relentless change. Obviously students must be taught to manage and use technology but more is needed. They must also be taught to think about how these inventions will fit into the human experience. Perhaps the biggest misconception is that we have lot of time.

Suppose Kurzweil's prediction that by 2020 scientists will develop a computer model of how the brain functions. The age of strong artificial intelligence will be upon us. Students who are college freshmen today will be 38 years old in 2020. Ten years later, 2030, according to Kurzweil, the 
non-biological part of our intelligence will dominate. By 2045, the year of the singularity these students will be 63 and planning for retirement. Explaining Kurzweil's predictions in these terms helps students appreciate the fact that their lives could be affected by these technologies. Kevin Kelly's Out of Control offers a way of thinking about this possibility. Kelly believes that natural and artificial systems obey the same rules. Kurzweil's prediction that artificial system will match human system ignores the fact when this synthesis is made, the same rules human implanted in those system will make the artificial system replicate human inefficiency.

Most students assume that they will be a part of this creative class that will create artificial complex systems. The fact that humans can expedite the creative process is part of the motivation of this creative class. The creative class, as Florida describes it, is now estimated at 38 million workers. Of these 15 million are in science, architecture, computer design, engineering, education and art/entertainment. This workplace is unlike any in our history. Creativity takes place in one's head and cannot be routinized. The creative worker will be a different type of organizational member and as such will present management with a different set of challenges. According to Florida the ideas of the creative class must be accommodated, or they will lose interest or go on to other ideas. They will work for companies that are solicitous to their emotional needs and more tolerant of their organizational lapses.

These allowances for these workers are necessary because of what Daniel Bell called a knowledge society (Bell, 1973). Production does not take place on an assembly line. The end of Fordism is irreversible. Production has to be organized differently and college education is almost a minimal requirement. Becoming technologically literate is an imperative. Person and Young (2002, p. 9) outlined the characteristics of a technologically literate citizen (Figure 1).

\section{KNOWLEDGE}

* Recognizes the pervasiveness of technology in everyday life.

*Understands basic engineering concepts and terms, such as systems, constraints, and tradeoffs.

*Is familiar with the nature and limitations of the engineering design process.

* Knows some of the ways technology shapes human history and people shape technology.

* Knows that all technologies entail risk, some that can be anticipated and some that cannot.

* Appreciates that the development and use of technology involves trade-offs and a balance of costs and benefits.

* Understands that technology reflects the values and culture of society.

\section{WAYS OF THINKING AND ACTING}

* Asks pertinent questions, of self and others, regarding the benefits and risks of technologies.

* Seeks information about new technologies.

* Participates, when appropriate, in decisions about the development and use of technology.

\section{CAPABILITIES}

* Has a range of hands-on skills, such as using a computer for word processing and surfing the Internet and operating a variety of home and office appliances.

* Can identify and fix simple mechanical or technological problems at home or work.

* Can apply basic mathematical concepts related to probability, scale, and estimation to make informed judgments about technological risks and benefits.

Figure 1. Characteristics of Technological Literacy 
Given this description, Americans have long way to go to achieve the goal of technological literacy. We, as teachers, can help by espousing a norm of inquiry and open-mindedness. We can do this by pointing out how technology has changed our disciplines. For example, the Internet has made more sources available for the all disciplines. Humanities and social sciences are in an exponential growth period. Studying how people react to technology is interesting but the onslaught will not spare any discipline. Online capacity enables teachers to "access" materials on a subject from all over the world. The so-called chat rooms hold incredible potential for learning. As the cost of telecommunication declines, there could be millions of such chat rooms.

In the future teachers at small colleges will have less costly access to the books and resources in the world's great libraries. This access will allow them to read the primary sources and save money on travel. Scientists in different countries now work on the same problems (e.g. stem cell research). They know what their oversea colleagues are doing and can communicate with them instantly. The advantage prestigious American and European universities have with the monopoly on books, scholars and resources could be challenged if more information were available online. Simply put, the online capacities will be the great equalizer of universities. This is not say that universities in China or India will the rival prestige of Oxford, Harvard, Stanford and MIT, but that researchers and their students will have considerably more information.

In this avalanche of information, new gadgets, and medicine, technological literacy requires constant retooling. The new creative workers will not be able to keep up unless they become permanent students. Unlike their parent's generation, they will not be able to put their books away after college. The workplace will change as a reaction to technology. The passage from college to the office or laboratory will not be marked by a uniform code of dress but rather by what Florida calls a "no collar" environment of informality. According to Florida, creative workers will be managed by what are called "soft controls" (e.g. emotions) rather than financial incentives. Knowledge producing organizations such as universities, research and development firms, think tanks and financial management firms are among the less formal work style leaders of the post-industrial society. Relations among the employers may be the role models for the new generation of workers. Yet many of these organizations are in what William Ogburn (1964) called a "cultural lag”. A cultural lag occurs when society has changed, but people insist on clinging to old customs. There are also technological lags. People may insist on using old ways when new technology is more efficient, safe and effective.

Accordingly, it is incumbent upon teachers to prepare students to meet and adjust to the new world of technology. First, students need to be taught how to keep an open mind and be ready to address changes in work and routines. Second, students should be prepared for more job changes than their parents. Third, students should expect to technology to surprise them. Most predictions of the future are only guesses. One invention or finding can change an entire way of thinking. Thomas Kuhn called this a paradigm shift. Once the fundamental change in thinking occurs, many new types of technology will follow. Accordingly, students must also be prepared to anticipate change and be ahead of the swing of the pendulum.

\section{Congruency and Preparedness}

Congruency is defined as adjusting ones self to the challenge of technology and harnessing the opportunities of that technology. Congruency is not to be confused with acquiescence or attempting to achieve the right fit between human and technology. Congruency is not letting things happen to us, it being proactive and adaptive. Teachers, students and other consumers must contest the work of scientists. Scientists must expect these challenges. They must be alert and not to become too jaded by technology. For a democratic society, drawing boundaries for technology should be a priority. Yet at the same time, they should keep in mind the possibility that technology should provide us with time to devote to human relations. 
If students are to meet these challenges they must be prepared to addresses the new technology appropriately. Responses depend upon which scenario you believe. People may publicly disagree with heaven scenario of Kurzweil and his cohorts but privately they wish these scientists well and hope for the full range of technological imagination. They want to end poverty, clean up the environment, reverse global warming, find new energy sources and of course live longer. The quest for immortality has a long history in the human experience. Biomedical scientists continue to solve puzzles of the human body.

If one is convinced that hell scenario is likely or even possible, one can find a lot of literature to support pending human disasters. This possibility has some perverse appeal. There are books claiming to have located disquieting signs, incorrect scientific predictions and unexpected outcomes. Apocalyptic stories are more dramatic and compelling. Adherents to the hell scenario do not believe that equality flows from more resources. Humans are capable of all types of miscalculation and misdeeds. Present day society allows the rich and powerful to hoard resources and capital, why wouldn't the rich and powerful do the same with the fruit of technology? There is no guarantee that the rich and powerful will share these new resources. Indeed, these new technologies could lead to even more disparities in society. Students inclined to believe this scenario are more likely to be skeptical and question the ethical issues associated with new technology. They believe that in the long run unregulated technology could cause unimagined problems. Accordingly, choices have to be made before it is too late. Otherwise human will have to adjust to technology rather technology adjusting to human.

Those who subscribed to the prevailing scenario make the argument that the human-technology nexus is the essence of the post-modern society. Human beings are what technology has allowed us to become. Evolution is immutable and inevitable. This is what human beings do. History shows that humans will prevail because they are human. They will find a way to co-exist with technology. Granted there will be some winnowing out but for most part human will decide the boundaries of technology. Any suggestion that technology can override human preferences is sheer science fiction. Society will welcome and expect machines to change our way of living and how we relate to other human beings. We accept the gadget immediately and correct for the externalities later. For example, we embraced the cellular telephone without fully understanding how it would change human behavior. Who would have predicted that people would talk loudly on the street and use them while driving automobiles? Who thought a time saving device like the Blackberry would increase work for employees? Who predicted the hours at the computer would create serious ergonomic problems?

\section{The Anticipatory Response}

Anticipatory response is defined as the acumen to discern how technological changes will affect everyday life. What if nanotechnology is able to do all the things its proponent's claim it will? What if solar energy becomes efficient and reliable energy for industry and home? Understanding technology is a necessary but anticipating the trend that technology will generate is more important. Inventions come and go. We can vote on them with our pocketbooks. Rather than approach the future with trepidations, we should endeavor to improve our prediction of it. Currently there are professionals organized around predicting the future. These are not fortunetellers or soothsayers, but professionals trained to speculate about what will happen if certain trends continue. They try to answer such questions as: What happens if a machine can do a human task more efficiently and effectively? What happens if there is a breakthrough in medicine that eliminates cancer? How will the development of alternative fuels change geo-politics? They employ all types of techniques from brainstorming to the Delphi technique of making predictions.

Teachers must help their students appreciate these methods and employ them when appropriate to career planning. Scientific breakthroughs in the workplace will force students to ask more ques- 
tions. Why was $\mathrm{X}$ invented? Could it be used for other purposes? How will it change my job? Utopians argue that technology will improve our world, but advantages go to those who can anticipate change and make quick adjustments or preemptive career decisions. Dystopians are not so sure that all the social adjustment can be made, prudence requires an effort to be made. The reality may not be in binary terms. The anticipatory response requires a constant inventory of skills and information about technology breakthroughs. A job that requires college education is just as vulnerable to job elimination as are others (Blinder, 2006).

Preparedness is an imperative for the next generation. To do so, they must try to guage the impact of rapid change and design ways to cope with the new possibilities. The following are suggestions for the next generation.

1) They should make certain that the regulation of science reflect our values. It is imperative that they do not become too enamored of the fruit of technology that we acquiesce to scientists pushing the envelope (creating harmful environment agents or biological mutants-because they can)

2) They should make sure that the students not only understand technological trends but also co-opt them. Staying ahead of the curve and thinking outside the box should be the norm.

3) Managing worker displacements will be the burden of the next generation regardless of which technological scenario triumph.

Preparing for a world in which work as we know it is changing at incredible speed will be difficult. We have to believe, however, that new work will be found. Work organizes the human experience. Even if some work becomes obsolete, many people will want to do it as matter of lifestyle preferences or out of necessity.

\section{Conclusions}

Teaching has always been about values. Yes, we teach history and economics, environment, government, health, information, and culture, but our main goal is to determine the rules by which to live and work. Accepting technological changes in our lives is a value. The demand of a creative society requires us to do so. This is a challenge that threatens teaching, as we know it. Sure it is easy to make fun of Ray Kurzweil's notion of a hybrid biomechanical life form, his excessive use of the word "exponential," and his quest for immorality, but the rise of super science is not near, it is here. Equally it is easy to ridicule James Hughes's notion of democratic transhumanism (2004). The democratic process may not yield a polity in which all technologies will be safe and available to everyone equally. The same group of elites who dominate politically and economically will continue to do so.

More importantly technology and its concomitant secularization shake traditional pedagogy to its core. We, as teachers, cannot pretend we are current with these changes. We must work harder to understand them. It is not time for dramaturgy. Students today often are more computer and technologically literate than their teachers, but they need values to guide the application of this knowledge. For example, just because a research paper is purchased online does not mean it can be submitted for a class, nor is it right to introduce a virus onto the Internet.

No previous generation has endured this type of worldwide and irreversible change. Being prepared, for it will be difficult. Teachers must be able to explain these changes and prepare students for possible unintended consequences of human ingenuity. Individualism may not be eliminated as Huxley predicted but there is real danger of relying on what Jacques Ellul calls the technique. Finding a technique becomes an end rather than a mean. Society has to be more than a collection of techniques. 
Another hidden danger is that society will become over invested in technology at the expense of human welfare. The excitement about technology has increased faith in science. Science seems so rational and free of fraud. For many it is difficult to imagine that the scientific community can make a catastrophic mistake. Some people are convinced that humans will be able to control machines--science fiction movies to the contrary. Others like Kevin Kelly are not so sure. There is always the possibility of abuse of technology. In any case, we need to begin the discourse about technology and our relationship with it.

This essay is not to suggest that teachers become the new Luddites, a group that opposed automation because it replaced manufacturing workers, nor should we join the ranks of futurists, trendspotters, corporate strategists, forecasters and visionaries. Rather this essays attempts to inveigle teachers to become enlightened mentors for this new generation. The year 1984, the dawn of the $21^{\text {st }}$ Century, and 9/11 have come and gone but there is still no Orwellian world. Neither is there recognition that technology is not risk free. We are still on that train that Arthur Hunt described earlier. Teachers can no longer be just passengers, they must become conductors. Students are willing to adjust their values as technological changes flood their daily lives. They are attracted to the idea of a "creative class" and the prospect of a pedantocracy-m political leadership based on talented. A world without wants is a worthy goal. It is also a promise several prophets made.

The next generation will reap the fruits of technology and enjoy it. We must teach students to be more congruent and anticipatory in their responses rather than let technological glitz overwhelm them. Teachers must always make student aware that new technology involve risk. It is the burden of every generation to welcome the extraordinary degree and pace of technology. In the long run, they will benefit if this openness to technology is available in all parts of every curriculum.

\section{References}

Bell, D. (1973). The coming of the post-industrial society. New York: Basic Book.

Bennis, W. \& Slater, P. (1968). The temporary society. New York: Harper \& Row.

Bimber, B., Bennett, W. L. \& Entman, R. (2003). Information and American democracy: Technology in the evolution of political power. London: Cambridge University Press.

Blinder, A. (2006). Fear of offshoring: The next industrial revolution? Foreign Affairs, 85 (6), 113-128.

Dugger, W.E. (2001). Standards for technological literacy. Phi Delta Kappan, 82 (7), 513-517.

Ellul, J. (1973). The technological society. New York: Knopf.

Florida, R. (2002). The rise of the creative class: And how it's transforming work, leisure, community, and everyday life. New York: Basic Book.

Friedman, T. (2005). The world is flat: A brief history of the twenty-first century. New York: Farrar, Straus and Giroux.

Garreau, J (2004). Radical evolution: The promise and peril of enhancing our mind, our bodies—and what it means to be human. New York: Doubleday.

Harris, D. N, Handel, M. J. \& Mishel, L. (2004). Education and the economy revisited: How schools matter. Peabody Journal of Education, 79 (1), 36-63.

Hughes, J. H. (2004). Citizen Cyborg: Why democratic society must respond to the redesigned humans of the future. New York: Westview Press.

Hunt, A. (2000). Tomorrowland: The future is here - Isn't mesmerizing? Christian Research Journal, 23(1), 2.

Huxley, A. (1932). Brave new world. London: Harper and Brother. 
Kelly, K. (1994). Out of control: New biology of machines, social systems and the economic world. New York: Perseus.

Knoke, W. (1996). Bold new world. New York: Kodansha International.

Kunster, J. (2005). The long emergency surviving the converging catastrophes of the twenty-first century. New York: Atlantic Monthly Press.

Laabs, J. (1992). Surveillance: Tool or trap. Personnel Journa,l 71(6), 96-105.

McLuhan, M \& Fiore, Q. (1967). The medium is the massage. NY: Bantam Books.

National Commission on Excellence in Education. (1983). A nation at risk: The imperative for education reform. Washington, D.C..

Ogburn, W.F. (1964). On culture and social change. Chicago: University of Chicago Press.

Pearson, G. \& Young, A.J. (2002). Technically speaking: Why all Americans need to know more about technology. The Technology Teacher, 62 (1), 8-12.

Posner, M. (2000). Technology: Can Congress keep up? National Journal, 32, 1.

Rifkin, J. (1995). The end of work: The decline of the global labor force and the dawn of the prost-market era. New York: Tarcher/Putnam Books,

Roche, E. M. (1997). Cyberopolis: The cybernetic city faces the global economy. In M. E. Craghan \& A. Vourvoulias-Bush (Eds.), The City and the world. New York: Council on Foreign Relations.

Toffler, A. (1970). Future shock. New York: Bantam.

\section{Biography}

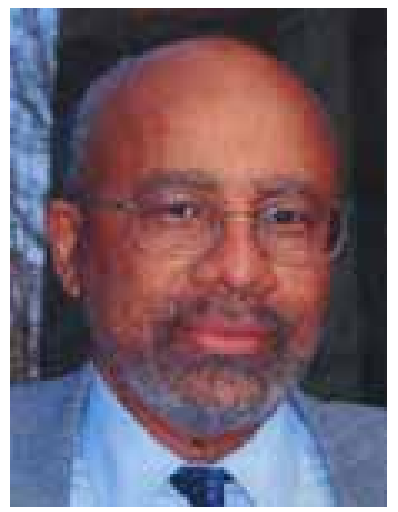

Wilbur C. Rich is a Professor of Political Science at Wellesley College in Massachusetts (USA). His central interest is the relationship of technology and public policy. 